\title{
Evaluation of butyrylcholinesterase and acetylcholinesterase activity in serum and saliva of myocardial infarction patients
}

\author{
Neda Omidpanah ${ }^{1}$, Negin Jalilian ${ }^{2}$, Asad Vaisi-Raygani ${ }^{3}$, Masoud Sadeghi ${ }^{4}{ }^{\oplus}$, Hamid Reza Mozaffari $^{1,4}, *(1)$
}

${ }^{I}$ Department of Oral and Maxillofacial Medicine, School of Dentistry, Kermanshah University of Medical Sciences, Kermanshah, Iran

${ }^{2}$ Students Research Committee, Kermanshah University of Medical Sciences, Kermanshah, Iran

${ }^{3}$ Department of Clinical Biochemistry, Kermanshah University of Medical Sciences, Kermanshah, Iran

${ }^{4}$ Medical Biology Research Center, Kermanshah University of Medical Sciences, Kermanshah, Iran

\section{Correspondence}

Hamid Reza Mozaffari, Department of Oral and Maxillofacial Medicine, School of Dentistry, Kermanshah University of Medical Sciences, Kermanshah, Iran

Medical Biology Research Center, Kermanshah University of Medical Sciences, Kermanshah, Iran

Email: mozaffari20@yahoo.com

History

- Received: 07 July 2018

- Accepted: 09 October 2018

- Published: 26 October 2018

DOI :

https://doi.org/10.15419/bmrat.v5i10.491

\section{Check for updates}

\section{Copyright}

(c) Biomedpress. This is an openaccess article distributed under the terms of the Creative Commons Attribution 4.0 International license.

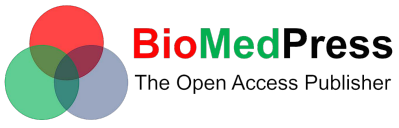

\begin{abstract}
Background: Myocardial infarction (MI) is one of the most common cardiovascular diseases. It accounts for about half of death cases in Iran. The objective of this study was to compare the activity of butyrylcholinesterase (BChE) and acetylcholinesterase (AChE) enzymes in serum and saliva of the MI patients compared to the healthy controls. Methods: Serum and salivary BChE and AChE levels were measured immediately following $\mathrm{Ml}$, and then 24 and 72 hours later. Four $\mathrm{mL}$ of blood and two $\mathrm{mL}$ saliva were collected for this purpose. These measurements were also collected in 30 healthy controls. The enzymes were assayed using spectrophotometry. Results: The activity of salivary $\mathrm{AChE}$ in the MI patients was lower than that of the healthy controls right after, 24 hours, and 72 hours following MI. However, serum AChE did not show a significant difference between the two groups. The activity of serum BChE in the MI patients was lower than that of the healthy controls right after, 24 hours, and 72 hours following MI. However, salivary BChE did not show a significant difference between the two groups. Conclusion: The activity of salivary AChE decreased in the MI patients compared to the healthy controls, which can be a marker to diagnose Ml in the future.

Key words: Acetylcholinesterase, Butyrylcholinesterase, Myocardial infarction
\end{abstract}

\section{INTRODUCTION}

Myocardial infarction (MI) is the permanent and irreversible death of myocytes that is caused by ischemia induced by the blockage in the blood supply into the affected region $^{1}$. In an MI attack, about one billion myocytes are destroyed which causes serious complications for cardiac function ${ }^{1}$. Cardiovascular diseases are responsible for one-third of all mortalities in the US in $2008^{2,3}$. Just in the US in 2004, more than 150,000 people died due to $\mathrm{MI}^{4}$. In addition, $\mathrm{MI}$ is also a huge cost burden on healthcare systems ${ }^{5}$. In Iran, $50 \%$ of all deaths are due to coronary artery disease (CAD), and evidence shows that the prevalence of CAD is increasing ${ }^{6}$. The World Health Organization (WHO) estimates that the prevalence of this disease is twice higher in males than in females ${ }^{7}$. CAD risk factors are lifestyle-related factors such as smoking, obesity, occupational stress ${ }^{8-10}$, air pollution ${ }^{11}$, poor socioeconomic status ${ }^{12}$, diabetes ${ }^{13}$, male gender, family history and, age ${ }^{14,15}$.

Considering the high prevalence of cardiovascular diseases, a detailed and comprehensive understanding of these diseases is highly necessary. Acetylcholinesterase (AChE) enzyme activity in the serum and saliva is one of the factors that have been studied to diagnose MI. Live cells have enzymes and proteins such as creatine kinase, troponin, and myoglobin.
When a myocyte dies, the cell membrane loses its integrity, and therefore enzymes and proteins are released into the circulation gradually. These enzymes and proteins can be detected by laboratory methods ${ }^{16,17}$. Acetylcholine is a neurotransmitter which, via the parasympathetic system, exerts inhibitory effects on the cardiac muscle and results in decreased excitability and increased resting membrane potential. In fact, functions of the cardiovascular system are significantly affected by the autonomic nervous system. Any abnormality in the function of this system due to pathologic conditions such as MI can result in increased cardiac arrhythmia ${ }^{18}$. Previous studies demonstrated that low plasma butyrylcholinesterase (BChE) activity might be related to decreased cardiac function $^{19}$. Low serum BChE activity is a prognostic marker of mortality associated with poor cardiac functions in acute myocardial infarction ${ }^{20}$. In another study, Sulzgruber et al. ${ }^{21}$ reported that BChE is a strong predictor for cardiac mortality specifically in younger patients with acute coronary syndrome aged between 45 and 64 years and BChE predicts cardiac mortality in young patients with the acute coronary syndrome. Best of our knowledge, the current study is the first to compare the serum and salivary AChE and BChE activity between MI patients and the healthy subjects. Herein, we decided to compare serum and 
salivary AChE and BChE activity between myocardial infarction and the healthy controls.

\section{METHODS}

This study was conducted in the University Hospital and was approved by the Ethics Committee of Kermanshah University of Medical Sciences, Kermanshah, Iran. Two groups were included (the MI group consisting of patients whose diagnosis was confirmed by board-certified cardiologists at the referral cardiology hospital and the control group consisting of healthy people without MI history). The control group was matched regarding age and gender to the MI group. In addition, the MI patients had no history of hemorrhagic stroke, neurologic disease, congestive heart failure, renal failure, hypothyroidism, severe asthma, and sepsis as case group.

\section{Samples Collection}

The peripheral blood samples were obtained from the brachial vein $(4 \mathrm{~mL})$ and were collected in Falcon tubes containing $0.025 \mathrm{M}$ EDTA. Then, the samples were centrifuged at $14000 \mathrm{rpm}$ for five minutes, and the isolated serum was immediately frozen at -45 ${ }^{\circ} \mathrm{C}$. Unstimulated saliva samples were collected in the morning ( 8 am to $10 \mathrm{am}$ ). $2 \mathrm{ml}$ of saliva was collected in five minutes, while the subjects had not drunk any water, nor eaten any food and had not smoked about two hours before sampling. Before sampling, the subjects thoroughly washed their mouth, and after several minutes saliva was collected into Falcon tubes. Then, the samples were centrifuged at $20.000 \mathrm{rpm}$ for 2-3 minutes, and the isolated transparent supernatants were immediately frozen at $-45^{\circ} \mathrm{C}$.

\section{Serum and salivary BChE measurement}

Firstly, serum and saliva samples were diluted (1:100) with $133 \mathrm{mM}$ phosphate buffer. For the test tube, 1 $\mathrm{mL}$ of distilled water and $2 \mathrm{~mL}$ of diluted saliva or serum sample was mixed with $1 \mathrm{~mL}$ of $200 \mathrm{mM}$ benzoylcholine chloride. In the blank tube, equal volumes of distilled water and serum or diluted saliva were added. The light absorbance at the wavelength of $240 \mathrm{~nm}$ at $25^{\circ} \mathrm{C}$ was measured after subtracting the absorbance of the blank tubes. Each sample was read five times in a five-minute period (every minute, one absorption). When benzoyl choline (200 nM) is hydrolyzed in a total volume of $4 \mathrm{~mL}$ and the absorption changes are $\Delta \mathrm{A}=0.33$, the serum and salivary $\mathrm{BChE}$ activity was calculated using the following formula:

$$
\frac{\triangle A / \min }{0.33} \times \frac{200}{1000} \times \frac{1000}{20}=\triangle A / \min x 30.3
$$

The normal value of this enzyme is $0.6-1 / \mathrm{Uk} 4 / 1$ (at $25^{\circ} \mathrm{C}$ ) and $1.08-1 / \mathrm{Uk} 4 / 2$ (at $37^{\circ} \mathrm{C}$ ). The additional details (chemicals, kits, instruments, etc.) were reported in the studies of Shahmohamadnejad et al. ${ }^{22}$ and Haghnazari et al. ${ }^{23}$.

\section{Serum and salivary AChE measurement}

Firstly, 100 landa of whole blood was irrigated with saline buffer for three times in a glass tube. After irrigation, the sample was centrifuged, and the supernatant was removed, and saline buffer was added. When irrigation finished, the supernatant was removed totally, and $10 \mathrm{~mL}$ of $50 \mathrm{mM}$ phosphate buffer was added. Then, in two cuvets (one for the test tube and one for the blank tube), $2 \mathrm{~mL}$ of DTNB was added. Then, $1 \mathrm{~mL}$ of cellular suspension was added to each cuvet and stored at 30C. After 3 minutes, 100 landa of the substrate was added to the cuvet containing the sample. At wavelength $412 \mathrm{~nm}$, light absorbance of the sample and blank tube were measured. Test tubes were read in a 5-min interval (one reading for every minute). Using the following formula, salivary and serum AChE activity was calculated:

salivary or serum $A C h E=\frac{\triangle A 412 / \min }{P C V} x 114$

The normal value of the enzyme is $8-1 / \mathrm{Uk} 13$.

\section{Statistical analyses}

Descriptive indices including frequency, percentage, mean and its standard deviation (SD) were used to express data. To determine the normal distribution of the data, the Kolmogorov-Smirnov (KS) test was used. To compare the enzyme values between different time points (i.e., immediately following MI, and hours 24 and 72 post-MI), repeated measures analysis of variance (ANOVA) was used. Whenever Mauchly's test of sphericity was statistically significant, the Greenhouse-Geisser test was applied. For paired comparisons, the Bonferroni's test was applied. For comparison of the variables between the MI and control groups, the independent sample T-test was used. To determine the correlation between serum and salivary enzyme measurements, the Pearson correlation test was used. The analyses were done by SPSS software (ver. 18.0). The significance level was set at less than 0.05 .

\section{RESULTS}

There were 30 patients in the MI group and 30 subjects in the control group. In each group, there were 25 males (83.3\%) and 5 females (16.7\%). The mean $( \pm \mathrm{SD})$ of ages in the MI and control groups were 
$52.37( \pm 6.42)$ and $50.73( \pm 7.36)$ years respectively; $\mathrm{P}=0.364$. The KS test showed that the variables had a normal distribution $(\mathrm{P}>0.05)$.

The mean serum AChE levels immediately following MI, 24 hours and 72 hours post-MI were 12.65, 12.61, and 12.41, respectively (Table 1 ). There was no significant difference in AChE measurements at these three time points $(\mathrm{P}=0.998)$ and also in each of three time points compared to the controls $(\mathrm{P}=0.713, \mathrm{P}=0.650$, and $\mathrm{P}=0.940$, respectively). The serum levels have been shown based on sex which shows no significant difference in both male and female at the three time points, but there was a significant difference at each time compared to the controls.

As seen in Table 2, there is a significant difference in the salivary AChE level between the control and MI groups at the three time points $(\mathrm{P}<0.001$ immediately, $\mathrm{P}<0.001$ in 24 hours, and $\mathrm{P}<0.001$ in 72 hours after $\mathrm{MI})$. The mean salivary AChE levels immediately following MI, 24 hours and 72 hours post MI were 0.406 , 0.434 , and 0.429 , respectively. The salivary levels have been shown based on sex which shows no significant difference in both male and female at the three time points, but there was a significant difference at each time point compared to the controls.

There were significant differences in the serum BChE level between the control and MI groups immediately following MI, 24 hours and 72 hours post-MI ( $\mathrm{P}=0.003, \mathrm{P}=0.008$, and $\mathrm{P}=0.002$, respectively). Repeated measures ANOVA did not show significant changes regarding serum $\mathrm{BChE}$ at the three time points $(\mathrm{P}=0.794)$; (Table 3$)$. The serum levels have been shown based on sex which shows no significant difference in both male and female at the three time points, but there was a significant difference at each time point compared to the controls.

As seen in Table 4, There was no significant difference in the salivary BChE level measured at the three time points $(\mathrm{P}=0.049)$ compared to the controls. In addition, the salivary levels have been shown based on sex which shows a significant difference in both male and female at the three time points, but there was no significant difference at each time point compared to the controls.

There was no significant correlation between the serum and salivary level of AChE immediately following $\mathrm{MI}(\mathrm{r}=0.08, \mathrm{P}=0.676), 24$ hours after $\mathrm{MI}(\mathrm{r}=$ $0.017, \mathrm{P}=0.929)$, and 72 hours after $\mathrm{MI}(\mathrm{r}=0.141, \mathrm{P}=$ $0.457)$. No significant correlation existed between the salivary and serum level of AChE in the control group $(\mathrm{r}=0.301, \mathrm{P}=0.106)$. Also, no significant correlation was found between the salivary and serum level of BChE immediately after MI $(\mathrm{r}=0.233, \mathrm{P}=0.242), 24$ hours after $\mathrm{MI}(\mathrm{r}=0.06, \mathrm{P}=0.771)$, and 72 hours after $\mathrm{MI}(\mathrm{r}=0.105, \mathrm{P}=0.642)$. No significant correlation existed between the salivary and serum level of BChE in the control group $(\mathrm{r}=0.356, \mathrm{P}=0.054)$.

\section{DISCUSSION}

Acetylcholine is the main neurotransmitter of the parasympathetic system, and its level is regulated by AChE and BChE through hydrolysis ${ }^{24-26}$. This study investigated the activity of AChE and BChE enzymes in the saliva and serum in patients with $\mathrm{MI}$ in comparison to healthy subjects to identify markers to diagnose of MI. MI is one of the common cardiac conditions $^{27}$, and its main cause is atherosclerosis. One study ${ }^{28}$ reported that serum AChE and BChE levels decreased following MI. The activity of these enzymes can be important in the development of MI and also be protective. Clinical findings and electrocardiography do not achieve the required sensitivity and specificity ${ }^{28}$. The measurement of these enzymes can be useful in managing patients suspected to suffer MI. A limited number of studies has been performed regarding the activity of $\mathrm{AChE}$ and BChE in the MI patients $^{27,29}$. One of the quick, cost-effective, and noninvasive methods for MI diagnosis could be the measurement of AChE and BChE activity in the serum and saliva. The previous studies have not been determined the changes in the activity of these enzymes in the saliva and serum of MI patients.

This study showed a significant decrease of AChE levels in the saliva of the MI patients compared to the control group immediately following MI, 24 hours and 72 hours post MI. We did not find any similar study in the literature assessing the salivary AChE and BChE levels in the MI patients. In a study by Mirzaii-Dizgah et al. ${ }^{30}$ including 30 salivary samples of patients with acute MI and 28 healthy subjects, salivary troponin level, as a marker for the diagnosis of MI, was higher in the MI patients than in the control group at 12 and 24 hours after MI. The observed findings in this study and increased salivary troponin levels in the mentioned study ${ }^{30}$ showed increased cardiac-related enzymes following MI. Our results showed decreased serum BChE levels in the MI group immediately following MI, 24 hours and 72 hours post MI. In a previous study, it was reported that MI patients with reduced $\mathrm{BChE}$ levels experienced a higher mortality rate ${ }^{29}$. As AChE and $\mathrm{BChE}$ enzymes are synthesized in cardiac muscle, their levels decrease after MI. This study is the first to investigate AChE and BChE serum and saliva levels in MI patients compared to the controls. During necrosis of 
Table 1: Comparison of serum acetylcholinesterase in the myocardial infarction and healthy groups

\begin{tabular}{lcccccccc}
\hline Healthy group & $\begin{array}{c}\text { Myocardial } \\
\text { infarction } \\
\text { group (first } \\
\text { hour) }\end{array}$ & $\begin{array}{c}\text { Myocardial } \\
\text { infarction } \\
\text { group (after 24 } \\
\text { hours) }\end{array}$ & $\begin{array}{c}\text { Myocardial } \\
\text { infarction } \\
\text { group (after } \\
\mathbf{7 2} \text { hours) }\end{array}$ & $\begin{array}{c}\mathbf{P} \\
\text { value }^{c}\end{array}$ & $\begin{array}{c}\mathbf{P} \\
\text { value }^{d}\end{array}$ & $\begin{array}{l}\mathbf{P} \\
\text { value }^{e}\end{array}$ & $\begin{array}{l}\mathbf{P} \\
\text { value }^{f}\end{array}$ \\
& Mean \pm SD & Mean \pm SD & Mean \pm SD & Mean \pm SD & & & & \\
Female & $13.34 \pm 0.397$ & $13.52 \pm 2.05$ & $12.74 \pm 1.69$ & $11.59 \pm 1.84$ & & & & \\
Male & $12.52 \pm 1.66$ & $12.48 \pm 2.94$ & $12.59 \pm 2.45$ & $12.57 \pm 2.61$ & 0.713 & 0.650 & 0.940 & 0.998 \\
Total & $12.65 \pm 1.55$ & $12.65 \pm 2.81$ & $12.61 \pm 2.32$ & $12.41 \pm 2.49$ & & & & \\
\hline
\end{tabular}

${ }^{c}$ Comparison between the control and myocardial infarction group (first hour)

${ }^{d}$ Comparison between the control and myocardial infarction group (after 24 hours)

${ }^{e}$ Comparison between the control and myocardial infarction group (after 72 hours)

${ }^{f}$ Comparison within the myocardial infarction group (first hour, after 24 hours, and after 72 hours)

Table 2: Comparison of salivary acetylcholinesterase between control and myocardial infarction groups

\begin{tabular}{|c|c|c|c|c|c|c|c|c|}
\hline & $\begin{array}{l}\text { Healthy } \\
\text { control }\end{array}$ & $\begin{array}{l}\text { Myocardial } \\
\text { infarction } \\
\text { group (first } \\
\text { hour) }\end{array}$ & $\begin{array}{l}\text { Myocardial } \\
\text { infarction } \\
\text { group (after } \\
24 \text { hours) }\end{array}$ & $\begin{array}{l}\text { Mmyocardial } \\
\text { infarction } \\
\text { group (after } \\
72 \text { hours) }\end{array}$ & $\begin{array}{l}\mathbf{P} \\
\text { value }^{c}\end{array}$ & $\begin{array}{l}\mathbf{P} \\
\text { value }^{d}\end{array}$ & $\begin{array}{l}\mathbf{P} \\
\text { value }^{e}\end{array}$ & $\begin{array}{l}\mathbf{P} \\
\text { value }^{f}\end{array}$ \\
\hline & Mean \pm SD & $\operatorname{Mean} \pm$ SD & Mean \pm SD & Mean \pm SD & & & & \\
\hline Female & $0.688 \pm 0.127$ & $0.478 \pm 0.155$ & $0.410 \pm 0.163$ & $0.452 \pm 0.133$ & $<$ & $<$ & $<$ & \multirow{3}{*}{0.480} \\
\hline Male & $0.596 \pm 0.241$ & $0.392 \pm 0.185$ & $0.439 \pm 0.178$ & $0.425 \pm 0.191$ & 0.001 & 0.001 & 0.001 & \\
\hline Total & $0.611 \pm 0.227$ & $0.406 \pm 0.151$ & $0.434 \pm 0.174$ & $0.429 \pm 0.181$ & & & & \\
\hline
\end{tabular}

${ }^{c}$ Comparison between the control and myocardial infarction group (first hour)

${ }^{d}$ Comparison between the control and myocardial infarction group (after 24 hours)

${ }^{e}$ Comparison between the control and myocardial infarction group (after 72 hours)

${ }^{f}$ Comparison within the myocardial infarction group (first hour, after 24 hours, and after 72 hours)

Table 3: Comparison of serum butyrylcholinesterase between the control and myocardial infarction groups

\begin{tabular}{|c|c|c|c|c|c|c|c|c|}
\hline & $\begin{array}{l}\text { Healthy } \\
\text { control }\end{array}$ & $\begin{array}{c}\text { Myocardial } \\
\text { infarction } \\
\text { group (first } \\
\text { hour) }\end{array}$ & $\begin{array}{l}\text { Myocardial } \\
\text { infarction } \\
\text { group (after } \\
24 \text { hours) }\end{array}$ & $\begin{array}{l}\text { Myocardial } \\
\text { infarction } \\
\text { group (after } \\
72 \text { hours) }\end{array}$ & $\begin{array}{l}\mathbf{P} \\
\text { value }^{c}\end{array}$ & $\begin{array}{l}\mathbf{P} \\
\text { value }^{d}\end{array}$ & $\begin{array}{l}\mathbf{P} \\
\text { value }^{e}\end{array}$ & $\begin{array}{l}\mathbf{P} \\
\text { value }^{f}\end{array}$ \\
\hline & $\operatorname{Mean} \pm \mathrm{SD}$ & $\operatorname{Mean} \pm$ SD & $\operatorname{Mean} \pm$ SD & $\operatorname{Mean} \pm$ SD & & & & \\
\hline Female & $2.46 \pm 0.329$ & $1.84 \pm 0.654$ & $2.44 \pm 0.434$ & $1.98 \pm 0.722$ & & & & \\
\hline Male & $2.37 \pm 0.577$ & $1.83 \pm 0.847$ & $1.81 \pm 0.775$ & $1.85 \pm 0.666$ & 0.003 & 0.008 & 0.002 & 0.794 \\
\hline Total & $2.39 \pm 0.540$ & $1.83 \pm 0.808$ & $1.92 \pm 0.761$ & $1.87 \pm 0.664$ & & & & \\
\hline
\end{tabular}

${ }^{c}$ Comparison between the control and myocardial infarction group (first hour)

${ }^{d}$ Comparison between the control and myocardial infarction group (after 24 hours)

${ }^{e}$ Comparison between the control and myocardial infarction group (after 72 hours)

${ }^{f}$ Comparison within the myocardial infarction group (first hour, after 24 hours, and after 72 hours) 
Table 4: Comparison of salivary butyrylcholinesterase between the control and myocardial infarction groups

\begin{tabular}{lcccccccc}
\hline & $\begin{array}{c}\text { Healthy } \\
\text { control }\end{array}$ & $\begin{array}{c}\text { Myocardial } \\
\text { infarction } \\
\text { group (first } \\
\text { hour) }\end{array}$ & $\begin{array}{c}\text { Myocardial } \\
\text { infarction } \\
\text { group (after } \\
\mathbf{2 4} \text { hours) }\end{array}$ & $\begin{array}{c}\text { Myocardial } \\
\text { infarction group } \\
\text { (after 72 hours) }\end{array}$ & $\begin{array}{l}\text { P- } \\
\text { value }^{c}\end{array}$ & $\begin{array}{l}\text { P- } \\
\text { value }^{d}\end{array}$ & $\begin{array}{l}\text { P- } \\
\text { value }^{e}\end{array}$ & $\begin{array}{l}\text { P- } \\
\text { value }^{f}\end{array}$ \\
& Mean \pm SD & Mean \pm SD & Mean \pm SD & Mean \pm SD & & & & \\
Female & $0.003 \pm 0.002$ & $0.004 \pm 0.002$ & $0.003 \pm 0.002$ & $0.002 \pm 0.002$ & & & & \\
Male & $0.003 \pm 0.002$ & $0.003 \pm 0.002$ & $0.003 \pm 0.002$ & $0.002 \pm 0.001$ & 0.827 & 0.752 & 0.097 & 0.049 \\
Total & $0.003 \pm 0.002$ & $0.003 \pm 0.002$ & $0.003 \pm 0.002$ & $0.002 \pm 0.001$ & & & & \\
\hline
\end{tabular}

${ }^{c}$ Comparison between the control and myocardial infarction group (first hour)

${ }^{d}$ Comparison between the control and myocardial infarction group (after 24 hours)

${ }^{e}$ Comparison between the control and myocardial infarction group (after 72 hours)

${ }^{f}$ Comparison within the myocardial infarction group (first hour, after 24 hours, and after 72 hours)

myocardium, the AchE released by injury of cholinergic nerve and AchE can be a parameter for MI diagnosis.

\section{CONCLUSIONS}

Our findings showed a significant reduction in salivary $\mathrm{AChE}$ and serum $\mathrm{BChE}$ in the MI group in comparison to the control group. As the main objective of this study was to measure these two enzymes following MI, the results suggest that salivary AChE can be used as a marker the to diagnose MI in the future. As this study was done for the first time, we suggested that further studies with a larger number of salivary samples and for longer follow-up times be performed in the future. With such studies, the definitive role of $\mathrm{AChE}$ and BChE in diagnosing and managing MI patients will be validated.

\section{COMPETING INTERESTS}

Authors have no conflict of interest.

\section{AUTHORS' CONTRIBUTIONS}

Neda Omidpanah: Design of the study and acquisition of data.

Negin Jalilian: Collection of data

Asad Vaisi-Raygani: Analysis and interpretation of data.

Masoud Sadeghi: Revision of the article and final approval of the version to be published.

Hamid Reza Mozaffari: Writing of the article.

\section{ACKNOWLEDGMENTS}

This paper is issued from the thesis of Negin Jalilian and financial support was provided by Kermanshah University of Medical Sciences (Project code: 95336).

\section{LIST OF ABBREVIATIONS}

MI: Myocardial infarction
BChE: Butyrylcholinesterase

AChE: Acetylcholinesterase

CAD: Coronary artery disease

SD: Standard deviation

KS: Kolmogorov-Smirnov

\section{REFERENCES}

1. Laflamme MA, Murry CE. Regenerating the heart. Nature Biotechnology. 2005;23:845-56. null. Available from: DOI: 10.1038/nbt1117.

2. Roger VL, Go AS, Lloyd-Jones DM, Benjamin EJ, Berry JD, Borden WB, et al. Heart disease and stroke statistics-2012 update: a report from the American Heart Association. Circulation. 2012;125:e2-220. null.

3. Mozaffarian D, Benjamin EJ, Go AS, Arnett DK, Blaha MJ, Cushman M. Executive summary. Circulation. 2015;131:434-41. null. Available from: Doi:10.1161/cir.0000000000000157.

4. Steg PG, James SK, Atar D, Badano LP, Blömstrom-Lundqvist $C$, Borger MA, et al. ESC Guidelines for the management of acute myocardial infarction in patients presenting with ST-segment elevation. European Heart Journal. 2012;33:2569-619. null. Available from: DOI:10.1093/eurheartj/ehs215.

5. Gupta R, Joshi P, Mohan V, Reddy KS, Yusuf S. Epidemiology and causation of coronary heart disease and stroke in India. Heart (British Cardiac Society). 2008;94:16-26. null. Available from: DOI:10.1136/hrt.2007.132951.

6. Yusuf S, Hawken S, Ounpuu S, Bautista L, Franzosi MG, Commerford $\mathrm{P}$, et al. Obesity and the risk of myocardial infarction in 27,000 participants from 52 countries: a case-control study. Lancet. 2005;366:1640-9. null. Available from: Doi: 10.1016/s0140-6736(05)67663-5.

7. Mathers C, Fat DM, Boerma JT. The global burden of dis ease: 2004 update; 2008. Available from: Doi:10.1016/b978012373960-5.00335-x.

8. Kivimäki M, Nyberg ST, Batty GD, Fransson El, Heikkilä K, Alfredsson $\mathrm{L}$, et al. Job strain as a risk factor for coronary heart disease: a collaborative meta-analysis of individual participant data. Lancet. 2012;380:1491-7. null. Available from: Doi:10.1016/s0140-6736(12)60994-5.

9. Lee IM, Shiroma EJ, Lobelo F, Puska P, Blair SN, Katzmarzyk PT, et al. Effect of physical inactivity on major non-communicable diseases worldwide: an analysis of burden of disease and life expectancy. Lancet. 2012;380:219-29. null. Available from: Doi:10.1016/s0140-6736(12)61031-9.

10. Steptoe A, Kivimäki M. Stress and cardiovascular disease. Nature Reviews Cardiology. 2012;9:360-70. null. Available from: DOI:10.1038/nrcardio.2012.45. 
11. Mustafić $H$, Jabre P, Caussin C, Murad MH, Escolano S, Tafflet M. Main air pollutants and myocardial infarction: a systematic review and meta-analysis. Journal of the American Medical Association. 2012;307:713-21. null. Available from: DOI:10. 1001/jama.2012.126.

12. Vyas MV, Garg AX, lansavichus AV, Costella J, Donner A Laugsand LE. Shift work and vascular events: systematic review and meta-analysis. BMJ (Clinical Research Ed). 2012;345:e4800. null. Available from: DOI:10.1136/bmj.e4800.

13. Buse JB, Ginsberg HN, Bakris GL, Clark NG, Costa F, Eckel R, et al. Primary prevention of cardiovascular diseases in people with diabetes mellitus: a scientific statement from the American Heart Association and the American Diabetes Association. Diabetes Care. 2007;30:162-72. null. Available from: DOI:10.2337/dc07-9917.

14. Graham I, Atar D, Borch-Johnsen K, Boysen G, Burell G, Cifkova $\mathrm{R}$, et al. European guidelines on cardiovascular disease prevention in clinical practice: executive summary: Fourth Joint Task Force of the European Society of Cardiology and Other Societies on Cardiovascular Disease Prevention in Clinical Practice (Constituted by representatives of nine societies and by invited experts). European Heart Journal. 2007;28:2375414. null. Available from: DOI:10.1093/eurheartj/ehm 316.

15. Shaw E, Tofler GH. Circadian rhythm and cardiovascular disease. Current Atherosclerosis Reports. 2009;11:289-95. null. Available from: DOI:10.1007/s11883-009-0044-4.

16. Amsterdam EA, Wenger NK, Brindis RG, Casey DE, Ganiats TG, Holmes DR. AHA/ACC guideline for the management of patients with non-ST-elevation acute coronary syndromes. Circulation. 2014;130:344-426.

17. Lansky AJ, Stone GW. Periprocedural myocardial infarction: prevalence, prognosis, and prevention. Circulation: Cardiovascular Interventions. 2010;3:602-10. null. Available from: Doi:10.1161/circinterventions.110.959080.

18. Schwartz PJ, Rovere MTL, Vanoli E. Autonomic nervous system and sudden cardiac death. Experimental basis and clinical observations for post-myocardial infarction risk stratification. Circulation. 1992;85:177-91. null.

19. Arbel Y, Shenhar-Tsarfaty S, Waiskopf N, Finkelstein A, Halkin A, Revivo M. Decline in serum cholinesterase activities predicts 2-year major adverse cardiac events. Molecular Medicine (Cambridge, Mass). 2014;20:38-45. null. Available from: DOI: 10.2119/molmed.2013.00139.

20. Sun L, Qi X, Tan Q, Yang H, Qi X. Low SerumButyrylcholinesterase Activity as a Prognostic Marker of Mortality Associates with Poor Cardiac Function in Acute Myocardial Infarction. Clinical Laboratory. 2016;62:1093-9. null. Available from: DOI:10.7754/Clin.Lab.2015.151013.
21. Sulzgruber $\mathrm{P}$, Koller L, Reiberger T, El-Hamid F, Forster $\mathrm{S}$, Rothgerber DJ. Butyrylcholinesterase predicts cardiac mortality in young patients with acute coronary syndrome. PLoS One. 2015;10:e0123948. null. Available from: DOI:10.1371/ journal.pone.0123948.

22. Shahmohamadnejad S, Vaisi-Raygani A, Shakiba $Y$, Kian A, Rahimi Z, Bahrehmand F. Association between butyrylcholinesterase activity and phenotypes, paraoxonase 192 rs662 gene polymorphism and their enzymatic activity with severity of rheumatoid arthritis: correlation with systemic inflammatory markers and oxidative stress, preliminary report. Clinical Biochemistry. 2015;48:63-9. null. Available from: DOI:10.1016/j.clinbiochem.2014.08.016.

23. Haghnazari L, Vaisi-Raygani A, Keshvarzi F, Ferdowsi $F_{\text {, }}$ Goodarzi M, Rahimi Z. Effect of Acetylcholinesterase and Butyrylcholinesterase on Intrauterine Insemination, Contribution to Inflammations, Oxidative Stress and Antioxidant Status; A Preliminary Report. Journal of Reproduction \& Infertility. 2016;17:157-62. null.

24. Darvesh S, Hopkins DA, Geula C. Neurobiology of butyrylcholinesterase. Nature Reviews Neuroscience. 2003;4:131-8. null. Available from: DOI:10.1038/nrn1035.

25. Soreq $\mathrm{H}$, Seidman S. Acetylcholinesterase-new roles for an old actor. Nature Reviews Neuroscience. 2001;2:294-302. null. Available from: Doi:10.1038/35067589.

26. Rowland JP, Rigby J, Harper AC, Rowland R. Cardiovascular monitoring with acetylcholinesterase inhibitors: a clinical protocol. Advances in Psychiatric Treatment. 2007;13:178-8. Available from: DOI:10.1192/apt.bp.106.002725.

27. Chan D, Ng LL. Biomarkers in acute myocardial infarction. BMC Medicine. 2010;8:34. null. Available from: Doi:10.1186/17417015-8-34.

28. Menache R, Kenda L, Shaked P, Schwartzman S, Lewinsk $\mathrm{U}$. The prognostic value of serum acetylcholinesterase in myocardial infarction. Theoretical and clinical considerations. Research in Experimental Medicine Zeitschrift fur die Gesamte Experimentelle Medizin Einschliesslich Experimenteller Chirurgie. 1982;181:181-7. null. Available from: Doi:10.1007/bf01851188.

29. Calderon-Margalit R, Adler B, Abramson JH, Gofin J, Kark JD Butyrylcholinesterase activity, cardiovascular risk factors, and mortality in middle-aged and elderly men and women in Jerusalem. Clinical Chemistry. 2006:52:845-52. null. Available from: DOI:10.1373/clinchem.2005.059857.

30. Mirzaii-Dizgah I, Riahi E. Salivary high-sensitivity cardiac troponin $\mathrm{T}$ levels in patients with acute myocardial infarction. Oral Diseases. 2013;19:180-4. null. Available from: DOI: 10.1111/j.1601-0825.2012.01968.x. 